Chimbi, G. T. \& Jita, L. C. Resurgence of Large Class Sizes and Pedagogical Reform in 21st Century Secondary School History Classrooms

\title{
Resurgence of Large Class Sizes and Pedagogical Reform in 21st Century Secondary School History Classrooms
}

\author{
Godsend T. Chimbi ${ }^{* 1}$ \& Loyiso C. Jita ${ }^{1}$ \\ *Corresponding Author: Chimbi.GT@ufs.ac.za \\ 1. University of the Free State \\ Received : 2021-08-04 \\ Revised : 2021-09-07 \\ Accepted : 2021-09-16 \\ dol $10.46303 /$ ressat.2021.24
} How to cite this paper: Chimbi, G. T. \& Jita, L. C. (2021). Resurgence of Large Class Sizes and Pedagogical Reform in 21st Century Secondary
School History Classrooms. Research in Social Sciences and Technology, 6(3), 45-63. https://doi.org/10.46303/ressat.2021.24
This is an Open Access article distributed under the terms of the Creative Commons Attribution 4.0 International license
(https://creativecommons.org/licenses/by/4.0/).

\section{Abstract}

This paper examines the interaction between class size and teachers' selection of teaching methods while implementing a new history curriculum in Zimbabwean secondary schools. Policy makers, parents, teachers, and students are worried about large class sizes because they are associated with higher dropout rates, less teacher-student interaction and rote pedagogy. Although class sizes had significantly declined in the latter half of the 20th century, the growth of online learning has witnessed class sizes ballooning in the 21st century, reigniting the class size debate. The large class size challenge has re-emerged in the developed North although the problem has never been resolved in the developing South. Using the theoretical lens of symbolic interactionism and a qualitative multiple case-study approach, data were collected over an eight-week period using document analysis, semi-structured interviews and lesson observations. Results seem to challenge the conventional view that large classes coerce teachers to use rote pedagogy and small classes encourage learner-centric practices. Teachers' choices of teaching methods were neither linked to class size nor new pedagogical policy. Instead, teachers' personal philosophy to instruction appeared to be the decisive factor to the teaching methods they used, rather than the size of the class. To promote pedagogical change, improving teacher quality appears a more valuable and cheaper investment than constructing new schools and employing more teachers to reduce class sizes.

Keywords: Class size, pedagogical reform, symbolic interactionism, reform implementation, history pedagogy 
Chimbi, G. T. \& Jita, L. C. Resurgence of Large Class Sizes and Pedagogical Reform in 21st Century Secondary School History Classrooms

\section{Introduction}

Despite concerted efforts to improve the quality of education by cutting down class sizes, it seems large classes are still with us in the $21^{\text {st }}$ century (Bold et al. 2018; Jepsen, 2015; Marais, 2016). Jacob et al. (2016) observe that "across the globe, trends in education have reflected significant increase in student enrolment" (p. 8). Consequently, class sizes have gone up, eroding some of the gains made in class size reduction in the second half of the $20^{\text {th }}$ century. Although class sizes had significantly gone down in the developed world over the past decades, the growth of technology- based online learning has seen class sizes ballooning leading to renewed interest in the class size debate (Lowenthal et al., 2019). It appears the large class size problem has re-emerged in the developed North; although the challenge had never been resolved in the developing South (Ajayi et al. 2017; Duflo et al. 2012; Lowenthal et al., 2019). Due to natural population growth and increased demand for education "school enrollment has universally increased over the past 25 years in low-income countries" (Bold et al. 2018, p. 1). Unfortunately, the increasing enrollments have not been matched with corresponding resource allocation to build more schools and employ more teachers, due to declining government expenditure on education, in most developed and developing countries. As a result, large classes have become a new challenge in the $21^{\text {st }}$ century.

\section{Background and aim of the study}

The effects of class size on teaching and learning have been studied extensively, but without reaching definite conclusions (Beattie \& Thiele, 2016; Ehrenberg et al. 2001; Fredriksson et al. 2012; Mosteller, 1995; Smith \& Glass, 1980). Studies on the relationship between class size and student achievement have tended to yield contradictory results. Some studies have come up with findings that support smaller classes. For instance, Jepsen (2015), found that smaller classes are associated with increased student achievement and are popular with students, parents, teachers, and policymakers. Conversely, large classes are associated with less teacherstudent interaction, rote pedagogy and higher dropout rates. However, Hattie (2009) argues that class size has a close-to-zero effect on learner performance and achievement.

Extant research has tended to focus mainly on class size and student achievement in standardized tests and examinations, without interrogating teachers' pedagogical practices when teaching classes of different sizes. Very few studies (see Ajayi et al. 2017; Carpenter, 2006; Parks-Stamm et al. 2016, for example) have explored how class size influences teachers' choice of teaching methods. This is the gap the current research intends to fill in by widening the scope of the class size debate and add new insights to the rather scanty literature on how class size influences teachers' selection of teaching methods and the implementation of new pedagogical policy. The aim of this paper, therefore, is to extend the discourse on the currently under-theorized theme of class size and teachers' implementation of new pedagogical reform policy in history classrooms. To unpack this aim, two key research questions undergird this paper:

- How does class size influence teachers' enactment of new pedagogical policy in secondary school history classrooms? 
Chimbi, G. T. \& Jita, L. C. Resurgence of Large Class Sizes and Pedagogical Reform in 21st Century Secondary School History Classrooms

- How can teachers' fidelity to prescribed pedagogical reform policy be enhanced when implementing a new curriculum in secondary schools?

\section{Theoretical Framework}

This paper is illuminated by the theory of symbolic interactionism. Symbolic interactionism is an offshoot of the American philosophical tradition of pragmatism (Klenke, 2016; Sandstrom et al. 2001). This theory explains the importance of actions between individuals as they create and negotiate definitions, meanings, reality, and knowledge. Plummer (2000) points out that; "the very origins and history of the theory are themselves a contested domain" (p. 2). George Herbert Mead (1863-1931) of the Chicago School of Sociology is widely credited for developing this theory, but so is his German contemporary Marx Weber (1864-1920) (Ritzer \& Smart, 2001). But the term 'symbolic interactionism' was only coined by Herbert Blumer in 1937 (Klenke, 2016). Blumer was a student of Mead. He took over Mead's classes after his death in 1931. So Blumer popularised symbolic interactionism as the empirical theory of Chicago sociology in the $20^{\text {th }}$ century.

We found symbolic interactionism to be an appropriate theoretical framework for this paper because it focuses on small-scale interactions between individuals, like those that occur in the classroom. The implementation of new pedagogical policy generated interaction between the teacher, the class and new reform policy. Carter and Fuller (2015) advise that "symbolic interactionism is fruitful for research in implementing policies by emphasizing multiple interpretations of policy intent and influencing meaning for those who are objects of the policies" (p. 7). The theory illuminated researchers' perceptions on how teachers and students gave different interpretations of the policy intents, negotiated meanings of the new history curriculum, and interrelated during lessons.

\section{Review of Related Literature}

\section{The complexity of the class size debate}

Some forty years ago, Glass and Smith (1979) remarked that "the notion is widespread among educators and researchers that class size bears no relationship to achievement. It is a dead issue in the minds of most instructional researchers" (p. 2). However, the class size debate refuses to be buried. Copeland (2017), for instance, found that large classes had a positive effect on learners. This empirical study established that, when learning in large classes university students enjoy community service and participation. Copeland (2017) concludes that "students did feel more obligated that they participate in community service after the course and had a higher attitude regarding the benefit of community service in their own lives" (p. 87). This finding goes against the grain of most existing literature and conventional wisdom, which assume that huge classes reduce students' opportunities to learn.

All this controversy shows that, despite attempts to bury the class size debate (Glass \& Smith, 1979; Hattie, 2009), class size remains an influential determinant of pedagogical practice. Hoxby (2000) acknowledges that "class size is difficult to study" (p. 1240). What makes the effects of class size slippery is that, given the same resources different teachers are likely to do different things with them. Even if teachers were to teach classes of the same size, with equal resources, what they do in each class is bound to differ because different teachers teach 
Chimbi, G. T. \& Jita, L. C. Resurgence of Large Class Sizes and Pedagogical Reform in 21st Century Secondary School History Classrooms

differently. This makes the class size debate a complex spiders-web which is non-linear and, therefore, worth exploring at greater depth.

\section{Defining class size}

The term class size is often used to mean the number of learners taught by one teacher or a set of teachers in one class. Adeyemi (2008) refers to class size as an educational tool used to describe the average number of students per class in a school. This definition emphasizes that class size exists within school and classroom settings. However, this definition may be obsolete with the coming in of virtual classes, which do not operate within school or classroom settings, due to advances in technology. Wadesango et al. (2016) explain that "class size refers to the number of pupils or students at a specific level taught together in the same environment by a single teacher" (p. 176). While the term class size may be relatively easy to define, there is no consensus among scholars on what constitutes a 'large class' and a 'small class.'

\section{Dimensions of large and small classes}

Like most concepts in education, a clear-cut definition of a large class is neither feasible nor desirable. While there is no agreement on the numerical size of a large class, there is consensus among scholars that as class size increases, student-teacher interaction decreases resulting in student learning declining (Hewitt \& Brett, 2017, Orellana, 2006). Large classes are associated with reduced opportunities to learn, thereby negatively affecting student achievement in tests and examinations. In the same vein, Maringe and Sing (2014) define a large class as "any class where the numbers of students pose both perceived and real challenges in the delivery of quality and equal learning opportunities to all students" (p. 763). Researchers, policy makers, parents, teachers and students are worried about large class sizes. This is mainly because "large class sizes lead to higher dropout rates, lower attendance, more cheating, reduced breadth and depth of subject matter, less instructor-student interaction, less instructor feedback, increased reliance on the lecture and less student involvement in class" (Lowenthal et al., 2019, p. 153).

The actual sizes of 'large classes' tend to vary depending on whether schools are in high-income industrialized North or low-income underdeveloped South (Duflo et al. 2012). Within-country variations in class sizes are also common because of existing socio-economic inequalities in one country. Parks-Stamm et al. (2016, p. 4) classify classes into three categories: small class - less than 15 students; medium class - 15 to 34 students; and large class -35 students and above. In the Tennessee class size study conducted in the USA from 1985-1992, classes with 13 to 17 pupils (for first grade) and 17 to 22 pupils (for other grades) were considered small classes. Any class with more than 22 learners was considered a large class (Chetty et al. 2011). The average teacher-pupil ratio in primary schools in the USA between 1984 and 2015 was 14 students per teacher (UNESCO, 2017).

Duflo et al. (2012) found that in Kenya, "as a result of increased enrolment and decreased teacher numbers, average class size in first grade in 2005 was 83, and some grade 1 classes had more than 100 pupils" (p. 7). But grade 1 classes in schools under the Extra Teacher Program (ETP) in Kenya had an average of 44 pupils per class in 2005. These within-country variations in class sizes reflect the socio-economic status of the school and, ultimately, the parents who finance it. The lower teacher-pupil ratio of 1:44, compared to the national average of 1:83 in 
Chimbi, G. T. \& Jita, L. C. Resurgence of Large Class Sizes and Pedagogical Reform in 21st Century Secondary School History Classrooms

2005, was a result of better resourced schools in Kenya recruiting students from high-income families. Such schools were able to hire extra teachers under the ETP.

In South Africa, the officially prescribed teacher-pupil ratio for primary schools is 1:40 and 1:35 for secondary schools (Marais, 2016). However, Ngcukana (2018) reports that there were 86 pupils crammed in a Grade 8 class at one Senior Secondary School in rural Mthatha, Eastern Cape. Some seven years earlier, Venktess (2011) found that one school in the same province had 150 Grade 1 learners packed in one classroom. In the same school, Grade 2 had 78 learners and Grade 4 had 70. But class sizes in private schools in South Africa are much smaller than those in public rural and urban schools. The teacher-pupil ratio in South Africa's largest private school operator, Curro Holdings, is approximately one teacher for every 15 pupils across its network of 110 schools (UNESCO, 2017). This reflects the gross socio-economic inequalities prevalent in South African society.

\section{Pioneering research on class size: Glass and Smith's thesis}

Seminal research on class size by Glass and Smith (1979) and Smith and Glass (1980) showed the positive effects of smaller class sizes on student achievement. Manageable workloads, high teacher morale and a positive attitude towards classroom instruction were associated with smaller classes. Smaller classes also had favorable effects on students' self-concept, participation in class and interest in school. Glass and Smith (1979) established "a clear and strong relationship between class size and achievement" (p. 15). The relationship appeared more pronounced at secondary school than at elementary grades, but was insignificant across different subject areas, gender, race, and other demographic features of the class. The differences in achievement and class size were most noticeable when students were taught in classes of 10, 20 and 40 pupils. Students performed better in smaller classes, making Glass and Smith (1979) conclude that "there is little doubt that, other things equal, more is learned in smaller classes" (p. 15).

\section{Class size and curriculum fidelity}

There appears to be a noticeable relationship between class size and teachers' adherence or compliance with curriculum reform policy. Using Glass and Smith's (1979) argument that more is learned in smaller classes, it can also be assumed that there is more curriculum fidelity in a smaller class than a larger one. Bas and Senturk (2019) define curriculum fidelity as; "the extent to which the components of the curriculum are implemented and adhered to as specified in the implementation guidelines, quality of curriculum delivery; and the extent to which the curriculum practitioners are ready to implement the program" (p. 168). So, curriculum fidelity can be viewed as teachers' faithfulness, loyalty, and compliance to officially prescribed curriculum or reform policy. In most education systems across the world, teachers are expected to implement new policy as given; with curriculum supervisory authorities enforcing compliance. Existing studies shed insights into how teachers taught different class sizes across time and space.

\section{The Tennessee class size study}

This eight-year (1985-1992) longitudinal experimental research, conducted in the state of Tennessee in the USA, is regarded as a classic and "the highest quality study" on class size 
Chimbi, G. T. \& Jita, L. C. Resurgence of Large Class Sizes and Pedagogical Reform in 21st Century Secondary School History Classrooms

(Jepsen, 2015, p. 3). It involved over 11000 students and their teachers. The study focused on the effects of class size reduction on learner performance, taking into cognisance the costs associated with constructing additional classrooms, creating new classes, and hiring more teachers (Chetty et al. 2011). Altogether 80 schools and 330 classes participated in the Tennessee study which involved kindergarten, first, second and third grade classes. Learners were studied in small classes of 13 to 17 , large classes of 22 to 25 , and larger classes of more than 25.

The results of the first four years of the study showed that, "smaller classes did produce substantial improvement in early learning" (Mosteller, 1995, p. 113). These results contradicted Glass and Smith's (1979) earlier findings which established that the effects of class size were more noticeable at secondary school than in elementary grades. The Tennessee study concluded that: students in smaller classes scored higher on standardized tests than those in larger classes and smaller classes had fewer disciplinary problems (Chetty et al., 2011). Teachers perceived themselves as more productive and efficient when they taught smaller classes than larger ones. In short, teachers were more motivated and professionally gratified in smaller classes than in larger classes. Learners also reported benefiting more when they were taught in smaller than in larger classes.

\section{Class size problem in the $21^{\text {st }}$ Century}

University class sizes in the USA appear to be much larger than the national class size average of one teacher for every 15 students at primary school (UNESCO, 2017). In a study conducted in US universities (Carpenter, 2006), small classes were classified as classes with less than 50 students, large classes as having between 50 and 100 students, and larger classes as having 100 or more students. Beattie and Thiele (2016) see increases in class sizes in US universities as inevitable in the $21^{\text {st }}$ century because of the increased demand for university education, shrinking state support for higher education since 2008, and increased enrolment in online courses (Lowenthal et al. 2019). A steady increase in university enrolment and declining state and federal funding resulted in class sizes reaching unprecedented levels.

Students learning in large classes in one USA university were asked to select the teaching methods they preferred their lecturers to use. The largest number of students (38\%) indicated that they preferred the lecture/discussion method because: "the approach forces me to be alert"; "allows me to contribute and ask questions"; and "is not as boring as lectures" (Carpenter 2006, pp. 17-18). The other methods the students favored were lecture (20\%), jigsaw (19\%), case study (13\%) and team project (10\%). Although the classes were large, students preferred some discussion rather than a pure lecture. They favored interactive methodologies than rote pedagogy.

In Zimbabwe's public universities, classes with up to 400 students in 'mass lectures' are a common sight (Wadesango et al., 2016). Zikhali et al. (2015) established that, "In large classes, lecturers may simply resort to the use of the traditional lecture method which does not ensure student engagement with learning material but reduces them to passive listeners" (p. 244); implying that large class sizes reduce learning opportunities in Zimbabwean universities. 
Chimbi, G. T. \& Jita, L. C. Resurgence of Large Class Sizes and Pedagogical Reform in 21st Century Secondary School History Classrooms

Despite the prescribed teacher-pupil ratio of 1:40 for primary schools and 1:35 for secondary schools in Zimbabwe, classes have ballooned beyond these recommended sizes since 2000. The Daily News (2017) found that the average teacher-pupil ratio in primary and secondary schools stands at 1:50. According to Wadesango et al. (2016) overcrowded classes with up to 60 students per class are a common sight in Zimbabwe. In some extreme cases one class can have up to 80 learners.

The persistence of the large class size challenge in both the developed and developing countries makes it necessary for reform implementation scholars to generate new insights into the dynamics of the class size debate in the technology driven $21^{\text {st }}$ century. This paper explores how class size influenced Zimbabwean secondary school history teachers' selection of teaching methods while implementing a new pedagogical reform policy.

\section{Research Methodology}

\section{Research approach}

This paper is a qualitative multiple-case study of four secondary school history teachers. Minichiello and Kottler (2010) advise that "qualitative researchers observe people in their natural setting so that they can learn from them what they are thinking, and more importantly, why they think and act the way they do" (p. 12). We found a qualitative multiple case study to be an appropriate research approach for exploring, examining, and explaining the interaction between the teacher, class size, and the new pedagogical reform policy. Each of the four history teachers was studied as an autonomous classroom practitioner with the freedom to select the teaching methods $s$ /he considered appropriate for implementing the new history curriculum.

\section{Research design}

This paper adopts grounded theory (Wright et al. 2017) as its research design. Wright et al. (2017, p. 54) advise that "using a grounded approach themes emerge from the data, rather than a priori themes." Grounded theory was first suggested by Glaser and Strauss (1967) who argue against the development of theory using logical deduction. They maintain that theory must emerge from the data itself using comparative analysis. The purpose of qualitative research is not to simply verify existing theory but to construct new theory using findings from research data as evidence.

Grounded theory is an appropriate research design for the current qualitative case study because the researchers did not start by proposing a theory or hypothesis which needed confirmation or rejection. Instead, two research questions were used to collect data on class size and teachers' selection of teaching methods while implementing a new history curriculum in Zimbabwean secondary schools. Theory construction only occurred after data was collected. The study generated theory from systematically obtained and comparatively analyzed data on how class size influenced four history teachers' classroom practice and fidelity to a new history curriculum they were implementing.

\section{Context of the study and sampling procedure}

This study was conducted in four schools selected out of 13 secondary schools in Chitungwiza, a dormitory town 30 kilometers south-east of Harare (the capital of Zimbabwe). The context 
Chimbi, G. T. \& Jita, L. C. Resurgence of Large Class Sizes and Pedagogical Reform in 21st Century Secondary School History Classrooms

within which research is conducted is very important in qualitative research because it influences the meanings constructed by research participants on issues under study (Albusaidi, 2019). The four schools were selected because they were relatively well resourced and were, therefore, better prepared to implement the new history curriculum disseminated into schools in January 2017.

Four history teachers were purposively sampled to participate in this multiple case study out of a target population of 42. Purposive sampling was chosen because "qualitative research is more concerned with detailed and in-depth analysis than with statistical accuracy" (Molise, 2021, p. 89). One history teacher was selected from each of the four secondary schools. The sampling criteria were a minimum of a degree in history, a diploma in history pedagogy and more than five years' experience as a history teacher. The other consideration was that the participant was willing to be observed while teaching the new history curriculum to one Form 3 class over a period of eight weeks. Three of these teachers were female and only one teacher was male. David (the male teachers) had 25 years' experience, Emmy had 11 years' experience, while Bessie and Angela had 10 years' experience each. These teachers were assumed to have adequate Pedagogical Content Knowledge to teach the new history curriculum. The characteristics of the four history teachers are summarized in Table 1.

Table 1: Participants Profile

\begin{tabular}{|c|c|c|c|c|c|c|}
\hline Teacher & Gender & Age & Experience & Qualifications & Class & Class size \\
\hline David & Male & 49 & 25 years & $\begin{array}{l}\text { M.Ed. Administration } \\
\text { B.Ed. History } \\
\text { Dip. Ed (Secondary) }\end{array}$ & Form 3D & 20 students \\
\hline Emmy & Female & 36 & 11 years & $\begin{array}{l}\text { B.A. (Honours) History } \\
\text { Grad. D.E. }\end{array}$ & Form 3E & 49 students \\
\hline Bessie & Female & 35 & 10 years & $\begin{array}{l}\text { B.Ed. History } \\
\text { Dip. Ed. (Secondary) }\end{array}$ & Form 3B & 45 students \\
\hline Angela & Female & 34 & 10 years & $\begin{array}{l}\text { M.Sc. Development } \\
\text { Studies } \\
\text { B.A. Ed. History \& } \\
\text { Religious Studies }\end{array}$ & Form $3 \mathrm{~A}$ & 49 students \\
\hline
\end{tabular}

Abbreviations: M.Ed. = Master of Education Degree; M.Sc. = Master of Science Degree; $B . E d .=$ Bachelor of Education Degree; B.A. Bachelor of Arts Degree; B.A. Ed. = Bachelor of Arts with Education Degree; Grad. D.E. = Graduate Diploma in Education; Dip. Ed = Diploma in Education.

\section{Instruments and procedures}

Three instruments were used to collect data: a document analysis protocol, semi-structured interview guides and lesson observation protocol.

\section{Document analysis protocol}

A pre-formatted document analysis protocol was used to pick the key guidelines on the teaching methods history teachers were expected to use as they implemented the new history curriculum. Documents analyzed included curriculum reform policy frameworks, the old and 
Chimbi, G. T. \& Jita, L. C. Resurgence of Large Class Sizes and Pedagogical Reform in 21st Century Secondary School History Classrooms

new history syllabuses, official circulars and textbooks teachers were using with their classes. Elements of change and continuity between the new and old syllabuses were also identified and scrutinized in preparation for the lesson observations to check teacher fidelity to new curriculum reform policy.

\section{Semi-structured interview protocol}

Three-tier semi-structured interviews were held with each teacher at the pre-observation, intermittent and exit stages of the eight-week fieldwork period, giving a grand total of 12 interviews. Interviews elicited teachers' views on how they interpreted and understood reform policy signals and the teaching methods they were expected to use. They opened dialogue on how teachers were closing (or opening) the gap between reform policy and classroom practice. Each in-depth interview lasted approximately an hour and was audio-recorded. The recorded interviews were transcribed verbatim into typed text for iterative analysis.

\section{Non-participatory lesson observations}

Intensive non-participatory lesson observations were carried out by the first researcher in the four selected classes over an eight-week period. The plan was to observe each participant teaching the new history curriculum to the same Form 3 class twice a week which would yield a total of 64 lesson observations. However, because of unanticipated events (like staff meetings, examination invigilation, and cultural festivals) 47 lessons were observed. Lesson observations were manually recorded by the first researcher on a preformatted lesson observation protocol as each lesson unfolded. Of particular interest were the teaching methods the teachers used and how they interacted with learners. The manually recorded lesson observations were later typed in preparation for analysis.

\section{Data analysis}

We used the grounded approach (Wright et al. 2017) to code the data from the documents, interviews, and lesson observations. Open coding was used to identify the traditional teaching methods, constructivist pedagogies and instances in which teachers talked or wrote about class sizes in the interviews, documents, and lesson observations. Codes for traditional teaching methods were exposition, narration, lower-order questions, and dictation. Codes for constructivist methods were primary sources (map, picture, cartoon, original document), text study, pair work, group work, presentation, class discussion and role playing.

Axial coding (Charmaz, 2006; Corbin \& Strauss, 2008) was used for comparative analysis and connecting common patterns and divergences in the interview transcriptions. The pedagogies teachers used in their lessons were compared with those recommended in the new history syllabus. The coded data were extracted and analyzed using comparative content analysis, intra and cross-case analyses, triangulation, data crystallization and thematic aggregation. Themes were identified as they emerged from the data instead of using apriori themes. The themes that emerged from the data analysis are official pedagogical policy, abnormal class size, rote pedagogy, myth of large class size and explaining constructivist pedagogy. These themes guide the presentation and discussion of findings that answer the current study's research questions. 
Chimbi, G. T. \& Jita, L. C. Resurgence of Large Class Sizes and Pedagogical Reform in 21st Century Secondary School History Classrooms

\section{Ethical considerations}

This paper is part of a larger qualitative multiple case-study conducted in Zimbabwe from 2016 to 2018. Permission to collect data was granted by the University of the Free State in May 2017 under Ethical Clearance No. UFS-HSD2017/0523. Access to targeted schools was granted by the Ministry of Primary and Secondary Education (Zimbabwe) in June 2017. To protect the identities of schools and participants, pseudonyms are used in this paper. Teachers participated voluntarily and were informed of their right to withdraw from the study with or without giving reasons.

\section{Findings and Discussion}

This study explores how class size influenced history teachers' enactment of a new pedagogical reform policy in Zimbabwean secondary schools by answering the two research questions that guide the study. The research questions are: How does class size influence teachers' enactment of new pedagogical policy in secondary school history classrooms; and how can teachers' fidelity to prescribed pedagogical reform policy be enhanced when implementing a new curriculum in secondary schools? The following sections present and discuss findings which answer these two research questions using the following themes: official pedagogical policy, abnormal class size and rote pedagogy, debunking the myth of large class size and the missing link between class size and teachers' selection of teaching methods.

\section{Official pedagogical policy}

The new History Syllabus which Form 3 classes were pioneering in 2017 stated that:

The teaching of History will be accomplished through the use of the following learner-centered and multi-sensory approaches: games and quizzes, simulation, video and film shows, educational tours, case study, group discussion, discovery, research, debate, role play, projects, folklore and e-learning. (CDTS, 2015, p. 2).

Reform policy stressed the importance of technology-based learning and learner centered pedagogy. But what exactly was happening in the classrooms?

\section{Large classes and rote pedagogy}

Form 3 classes that participated in this study were overloaded, except Form 3D. Form 3D had only 20 students because history was optional in this class. Form 3A had 49 students, Form $3 B$ had 45 and Form $3 E$ had 49. These classes were far above the teacher-pupil ratio of 1:35 recommended by the new curriculum (MOPSE, 2015). In the pre-observation interview, Angela (who taught Form 3A) complained that:

Our classes are too big, too many pupils, ranging from 46 to 50. Marking is not thorough; you can't give comments in every book, and you cannot correct every mistake. The students are too many for me to monitor, making me shun group work, fearing that the groups may make noise and pupils may get out of control.

A document analysis of Angela's schemes of work for Third Term 2017 showed that she did not plan to use group work in her lessons. In the 13 lessons observed in Form 3A, Angela did not 
Chimbi, G. T. \& Jita, L. C. Resurgence of Large Class Sizes and Pedagogical Reform in 21st Century Secondary School History Classrooms

use group work for fear that she would not be able to control the 49 learners. Rather she often used teacher exposition, text study, teacher explanation and class discussion.

The avoidance of group work for fear of disciplinary problems was also echoed by Bessie who taught Form 3B. She explained that:

I try to use a number of methods, but the main one which I use, because of the large numbers of our pupils, is pair work. Pair work is the main one because if you put them into larger groups, they give problems of class management and can make noise.

In the 10 lessons she was observed teaching, Bessie also avoided role play and dramatization. She narrated that:

To be honest with you, I did not use these methods [role-playing and dramatization] because of the issue of discipline on the part of the students. For example, if you assign pupils to role play religious leaders of the first Chimurenga and you say, 'You are Mbuya Nehanda or Sekuru Kaguvi,' they become overwhelmed and get out of hand. Instead of focusing on the real issues, they will start calling each other names. And even after the lesson, instead of calling those pupils with their original names, they will call them 'Nehanda' of 'Kaguvi'. There is the problem of discipline among these pupils, and after the role play, de-rolling is a problem.

In the interviews and informal discussions, Bessie often complained about the large class sizes at Bridge High School. She explained the relationship between class size, technology (un)availability and pedagogical reform in the exit interview:

The school has tried to source some resources for the new curriculum; but considering the numbers we have - classes of 40 to 50 students each - these textbooks are inadequate. I tried to photocopy some material for the new history curriculum, but they [school administration] said they did not have stationery. This becomes a challenge. As a teacher, I have to find a way out, and then you find me dictating the notes, giving the notes to the pupils, instead of them going out to find the information themselves.

Angela and Bessie's classroom practices and choice of teaching methods seem to speak to Opoku-Asare et al.'s (2014) findings in Ghana which showed that; when faced with abnormal classes, "teachers cannot practice a variety of methods, such as higher order questioning and active learning approaches. In fact, teachers are effectively confined to the 'chalk and talk' instructional method" (p. 128). Although they knew that rote pedagogy was against reform policy, it appears Angela and Bessie could not move away from this practice mainly because their classes were too big and instructional resources for the new curriculum were inadequate. Angela and Bessie's classroom practices reflect some relationship between rote pedagogy and large classes. However, Emmy appeared to be having completely different experiences with Form 3E which had 49 students. 
Chimbi, G. T. \& Jita, L. C. Resurgence of Large Class Sizes and Pedagogical Reform in 21st Century Secondary School History Classrooms

\section{Abnormal class size seems not to matter}

In the pre-observation interview Emmy explained how the abnormal size of Form 3E (49 students) influenced her teaching methods:

The classes are too big, that's one major challenge...This Form 3 history class I am teaching has 49 students. But in all my classes I have always used progressive methods. Even before the new curriculum, I had already moved from that teacher-dominated approach.

Although Emmy acknowledged that her class was overloaded, she argued that she had always used progressive pedagogy, even before the 2017 reforms. She elaborated that:

I have always been progressive. I acquired it from university. In the BA (Honours) in History, we used to research. And I saw it work - the research approach works, especially in history where students must search for information. My understanding of teaching methods was sharpened by the Postgraduate Diploma in Education [PGDE]. Understanding children better physically, psychologically - I got that from PGDE.

It seems Emmy's teaching methods were neither shaped by class size nor the new pedagogical policy, but by the nature of her university training and her personal belief that "the research approach works."

\section{Debunking the myth of large class size and rote pedagogy}

Fifteen lesson observations were made in Emmy's Form 3E during the Third Term of 2017. The large class size seemed not to deter Emmy from using learner-centered pedagogy, debunking the commonly held myth that large classes make teachers resort to rote pedagogy. Despite the abnormal class of 49 students, Emmy used picture, map, and text study; individual and group presentations; class discussions and role-playing. In all the 15 lessons observed, Emmy did not use rote pedagogy. The 49 students appeared eager to participate in the varied learning activities she engaged them.

In the intermittent interview Emmy explained why she had changed her teaching methods, even before the inception of the 2017 reforms. This is how she put it: 'Activity-based learning is exciting, children participate, and they understand better; they are motivated; even the results actually show that when children do it, they will understand better and pass.' It was also interesting that Emmy's classroom practices were ahead of official reform policy. Her classroom practice was rather unusual as literature (Cohen, 1990; Desimone, 2002; Fullan \& Miles, 1992) views schools as conservative institutions and teachers as conformists who cannot easily shed off old habits in pursuit of new practices. Emmy's practice ruffled feathers on existing literature as she appeared to have discarded old teacher-centered methods in favor of progressive practices. We sought to understand and explain Emmy's pursuit for constructivist pedagogical practice despite her large class size.

\section{Explaining constructivist practice in an overcrowded classroom}

Emmy traced her progressivism to how she was taught history at university. Her BA Honors degree exposed her to the intellectual benefits of historical research. The PGDE further 
Chimbi, G. T. \& Jita, L. C. Resurgence of Large Class Sizes and Pedagogical Reform in 21st Century Secondary School History Classrooms

exposed her to the psychology of learning and progressive methodologies long before the reform initiative of 2017. Her classroom experience had shown that students benefit cognitively when they do research on their own. Bessie's practice challenged Opoku-Asare et al. (2014) and Wadesango et al.'s (2016) findings which established that: when faced with large classes teachers resort to rote pedagogy. Emmy's teaching methods appeared to be determined by her personal philosophy to history instruction rather than the size of the class or policy prescriptions. Her classroom practice seems to speak to Garcia-Martinez and Tadeu $(2018$, p.1) who found that "secondary education is one of the most complex levels of the educational system" because a secondary school teacher becomes a subject specialist. This increases the tendency to be isolated from other teachers, resulting in the teacher developing unique teaching methods that may not be shared by other teachers, as was the case with Emmy.

Constructivist teachers like Emmy who enjoy progressive pedagogy are rare, but they exist. In a study of lead teachers in South Africa, Jita and Mokhele (2013) established that Mrs. Mafolofolo had included Environmental Education (EE) in her teaching of Natural Sciences "even before the changes to include it in the curriculum were drafted" (p. S129). This proactive stance was a result of Mafolofolo's love of nature and her personal philosophy that children understand better when they are "able to see, touch and feel the real-life specimen" (p. S129). Emmy seemed to share the same pedagogical philosophy with Mafolofolo because she (Emmy) also believed that "activity-based learning is exciting, children participate, and they understand better; they are motivated..." It appears that the teacher's personal philosophy to teaching, rather than the size of the class or pedagogical policy prescriptions, determines the teaching methods. This is the grounded theory emerging from the current study.

\section{Small class size and progressive pedagogy: The missing link}

David was observed teaching Form 3D which had only 20 students because history was optional in this class. Nine lessons (70 minutes long each) were observed in Form 3D. David explained that the double lessons allowed him to use interactive learner-centered methods, unlike the 35 minutes lessons.

The 20 students participated actively in class discussions and group presentations. In a postobservation conversation David proudly remarked that: "I am teaching students who want to do history, and the class of 20 is an appropriate class size for the new curriculum." The official teacher-pupil ratio for the new curriculum at secondary school level is 1:35 (MOPSE, 2015). So, David's class was below the officially prescribed size, which motivated him. He elaborated that, "With this manageable class I can pay attention to each individual student and mark more closely, giving detailed comments. I am assured of a $100 \%$ pass rate."

But how had the small class size changed his teaching methods in the light of the new pedagogical policy he was implementing? David was clear that:

This idea of curriculum reform - I cannot say we have reformed our curriculum in history because there is nothing which has completely changed. It's just a term we are using but nothing has changed. It's the same John we are today calling Thomas because we don't have new topics. The topics we were studying 
Chimbi, G. T. \& Jita, L. C. Resurgence of Large Class Sizes and Pedagogical Reform in 21st Century Secondary School History Classrooms

in the previous syllabus [2167] are the same topics we are studying in the new syllabus [4044].

David saw the 'new curriculum' as a myth, more of old wine in new bottles. He saw no real change in the content taught. Further probing revealed that David's understanding of the new reform policy was still evolving. He explained that:

This new curriculum thing is a new baby; we are not very clear right from the top to the bottom. We are still learning. But in a nutshell, the new curriculum has two new aspects. It has this idea of coursework and projects which we call continuous assessment... It also includes new subjects like Heritage Studies, Physical Education, Mass Displays, to just mention a few. And Agriculture is now compulsory for every student.

David admitted that he had not fully understood the new curriculum policy, although he was already implementing it. He saw confusion in the whole hierarchy, from the policymakers at the top (who developed the new curriculum) down to the teachers at classroom level. In the pre-observation interview David did not mention anything about changing teaching methods towards learner-centered pedagogy as one of the requirements of the new curriculum. While this could have been an oversight on his part, it may also be an indicator that he did not prioritize pedagogical reform as an important component of the new curriculum initiative.

In the nine lessons observed, David made extensive use of teacher exposition, lecturing and dictation. But he also sprinkled some text study, group presentations, class discussion and debate. In the intermittent interview, David explained the teaching methods he often used:

The methods we use when teaching history are different from mathematics. We have key methods like text study; usually we work from the known going to the unknown and we don't expect our students to be prophets - they must read. So, text study is one of the key methods we use in history because of the nature of historical knowledge. We also have teacher exposition; the teacher must be very knowledgeable. Before attacking the topic, the teacher must explain to students what he or she expects to cover and the depth of coverage. So, teacher exposition is very important.

Although he emphasized the use of text study in the interview, David appeared to place a lot of importance on teacher exposition. A sample from David's schemes of work for Weeks 7 and 8 shows that he tried to balance teacher-centered with learner-centered pedagogies, at least in the documents, although actual classroom practice remained heavily teacher-centric.

The teacher-centered methods David planned to use in Week 7 and 8 were teacher exposition, question and answer, note-making, and note-taking. But the new history syllabus recommends learner-centered methods only. Learner-centered pedagogies he intended to use were text study, class and group discussion, simulation, picture study and map study. Interestingly, the lesson observations during Week 7 and 8 revealed that his practice was still teacher dominated. David believed that: "The history teacher remains the master of the subject. Here and there the teacher must give students notes because it's not everything which is found in the school textbook." 
Chimbi, G. T. \& Jita, L. C. Resurgence of Large Class Sizes and Pedagogical Reform in 21st Century Secondary School History Classrooms

Table 2. The teaching methods David planned to use in Week 7 and 8

\begin{tabular}{|c|c|c|c|c|c|}
\hline $\begin{array}{l}\text { Week } \\
\text { ending }\end{array}$ & Work planned & Objectives & Source & $\begin{array}{l}\text { Methodology and } \\
\text { competencies }\end{array}$ & Evaluation \\
\hline $27-10-17$ & $\begin{array}{l}\text { Treaties signed } \\
\text { between } \\
\text { Lobengula and } \\
\text { Whites } \\
\text {-Examples of the } \\
\text { agreements } \\
\text { - The Tuli } \\
\text { Concessions } \\
\text { Grobler Treaty } \\
\text { - The Moffat } \\
\text { Treaty (1887) }\end{array}$ & $\begin{array}{l}\text {-By the end of the } \\
\text { week pupils should } \\
\text { be able to; name at } \\
\text { least four } \\
\text { agreements signed } \\
\text { between Lobengula } \\
\text { and the Whites } \\
\text { - State at least } 3 \\
\text { terms of the } \\
\text {-Tuli Concession } \\
\text {-Grobler Treaty } \\
\text { - Outline at least } 4 \\
\text { terms of the Moffat } \\
\text { Treaty }\end{array}$ & $\begin{array}{l}\text {-Step Ahead } \\
\text { Book } 3 \\
\text {-African } \\
\text { Heritage Book } \\
3 \\
- \text { 'O' Level } \\
\text { History of } \\
\text { Southern } \\
\text { Africa } \\
\text { - From Iron } \\
\text { Age to } \\
\text { Independence }\end{array}$ & $\begin{array}{l}\text { - teacher exposition } \\
\text { - Question and answer } \\
\text {-text and study } \\
\text { - Class and group } \\
\text { discussions } \\
\text { - simulations } \\
\text { - Picture study } \\
\text { - Map studying } \\
\text { - Note taking } \\
\text { - Note making }\end{array}$ & \\
\hline $03-11-17$ & $\begin{array}{l}\text { Era of Treaties } \\
\text { - The Rudd } \\
\text { Concession (1888) } \\
\text { - The Lippert } \\
\text { Concession } \\
\text { - Revision test }\end{array}$ & $\begin{array}{l}\text { - Name at least six } \\
\text { people present at the } \\
\text { signing of the Rudd } \\
\text { concession } \\
\text {-state at least six } \\
\text { written terms of the } \\
\text { Rudd Concession } \\
\text {-State at least six } \\
\text { non-written (verbal) } \\
\text { terms of the } \\
\text { Concession } \\
\text {-state at least six } \\
\text { terms of the Lippert } \\
\text { Concession }\end{array}$ & $\begin{array}{l}\text {-Step Ahead } \\
\text { Book } 3 \\
\text {-African } \\
\text { Heritage Book } \\
3 \\
\text {-'O' Level } \\
\text { History of } \\
\text { Southern } \\
\text { Africa } \\
\text { - From Iron } \\
\text { Age to } \\
\text { Indpedence } \\
\text {-Dynamics of } \\
\text { History book } 3\end{array}$ & $\begin{array}{l}\text { - teacher exposition } \\
\text { - Question and answer } \\
\text { - text and study } \\
\text { - Picture study } \\
\text { - Class and group } \\
\text { discussions } \\
\text { - Note taking } \\
\text { - Note making }\end{array}$ & \\
\hline
\end{tabular}

David found it difficult to use learner-centered methods only, as required by reform policy. Although he was aware of the progressive demands of the new history curriculum, he still believed that the teacher remains "the master of the subject." His personal philosophy to history instruction seemed to be his greatest impediment to instructional reform.

The struggle between tradition and change which characterized David's classroom practice supports Desimone's (2002) observation that: "trying to change teaching practice is one area of schooling which has proved the most resistant to change" (p. 434). David's pedagogical conservatism resonates with Cohen's (1990) observation that teachers tend to embrace and interpret changes within the context of their old habits and experiences. Spillane et al. (2002) and Coburn (2006) also emphasize that teachers' past experiences seem to shape the way they understand and implement (or fail to implement) curriculum changes.

\section{Conclusion}

The grounded theory emerging from the current study is that class size seems not to matter much when teachers select teaching methods. Teachers' teaching philosophy determine classroom practice more than the size of the class. This study has shown that class size does not influence teachers a lot when they interpret reform signals and select instructional methods. David had a small class of only 20 students, but he still regarded exposition and note 
Chimbi, G. T. \& Jita, L. C. Resurgence of Large Class Sizes and Pedagogical Reform in 21st Century Secondary School History Classrooms

giving as indispensable to history instruction. His personal philosophy made him rely on teacher-centered methods although he was aware that policy required him to use activitybased constructivist pedagogy.

Conversely, Emmy used learner-centered pedagogy in an overloaded class of 49 students. Her preference for learner-centric methods was a result of her training as a history teacher and her personal philosophy that learners benefit from activity-based learning. David and Emmy's case studies seem to indicate a missing link between class sizes, teaching methods and teachers' fidelity (or infidelity) to pedagogical reform policy. Even if class sizes are reduced and reform policy recommends learner-centered practice, teachers' teaching philosophy appear to be the decisive factor in determining the teaching methods they use.

Jespen (2015) recommends that "replacing the most ineffective teachers, would have significantly large returns - much larger than any conceivable class-size reduction program" ( $p$. 7). However, in many countries, discharging incompetent teachers from service is not easy because of the tenure system. Once teachers serve probation and become permanent employees it is often difficult to expel them from service on grounds of incompetency, mainly because assessing teacher performativity is a subjective process.

While class size reduction is a noble school reform initiative, it is expensive (Lowenthal et al. 2019). It may not be the most feasible alternative, especially in low-income countries that face budgetary constraints. Teacher professional development appears to be a more pragmatic and affordable strategy than constructing more schools and employing more teachers. Exposing teachers to new ideas, improving their pedagogical content knowledge, and engaging them in curriculum reform discourse appears to be a cheaper alternative for most developing countries. If teachers are consulted when new reform policy is crafted, they are more likely to have a sense of ownership of the proposed reforms. Empowering teachers with new pedagogical knowledge and skills can nurture fidelity to new pedagogical policy.

The major limitation of the current multiple case study is that it involves only four history teachers, limiting the generalizability of the findings. Future research can widen the scope of the class size debate by increasing sample sizes and interrogating how teachers of other subjects are implementing new reform policies. Involving more teachers and classes in qualitative, quantitative and mixed methods studies may generate novel insights into how class sizes influence classroom practice and promote (or hinder) teacher fidelity to new pedagogical policy. Teacher professional development appears more feasible and economic, than building more schools, cutting down class sizes and employing more teachers. Policymakers need to invest more in teacher capacity building to improve teacher fidelity to pedagogical reform implementation. 
Chimbi, G. T. \& Jita, L. C. Resurgence of Large Class Sizes and Pedagogical Reform in 21st Century Secondary School History Classrooms

\section{References}

Adeyemi, T.O. (2008). The influence of class size on the quality of output in secondary schools in Ekiti State, Nigeria. American-Eurasian Journal of Science Research, 3(1), 7-14.

Ajayi, O.V., Audu, C.T., \& Ajayi, E.E. (2017). Influence of class size on students' classroom discipline, engagement and communication: A case study of senior secondary schools in Ekiti state, Nigeria. Sky Journal of Educational Research, 5(5), 60-67.

Albusaidi, S. (2019). Critiquing a qualitative study using Tracy's big-tent criteria. Research in Social Sciences and Technology, 4(1), 105-122. https://ressat.org/index.php/ressat/article/view/396/57

Bas, G., \& Senturk, C. (2019). Teaching-learning conceptions and curriculum fidelity: A relational research. International Journal of Curriculum and Instruction, 11(2), 163180.

Beattie, I.R., \& Thiele, M. (2016). Connecting class size? College class size and inequality in academic social capital. The Journal of Higher Education 87(3), 332-362. http://www.skyjournals.org/SJER

Bold, T., Filmer, D., Martin, G., Molina, E., Rockmore, C., Stacy, B., Svensson, J. \& Wane. W. (2018). What do teachers know and do? Does it matter? Evidence from primary schools in Africa. Policy Research Working Paper 7956, World Bank Group, 1-35.

Carpenter, J.M. (2006). Effective teaching methods for large classes. Journal of Family and Consumer Science Education, 24(2), 13-23.

Carter, M. J., \& Fuller, C. (2015). Symbolic Interactionism. Sociopedia. Isa

Charmaz, K. (2006). Constructing Grounded Theory: A Practical Guide through Qualitative Analysis. Sage.

Chetty, R., Friedman, J.N., Hilger, N., Saez, E., Schanzenbach, D.W. \& Yagán, D. (2011). How does your kindergarten classroom affect your earnings? Evidence from Project Star. The Quarterly Journal of Economics, 126(4), 1593-1660. Doi:10.1093/qje/qjr041

Coburn, C.E. (2006). Framing the problem of reading instruction: Using frame analysis to uncover the micro processes of policy implementation. American Educational Research Journal 43(3), 342-379.

Cohen, D. K. (1990). A revolution in one classroom: The case of Mrs Oublier. Educational Evaluation and Policy Analysis, 12(3), 311-329.

Copeland, L. (2017). International trade service-learning attitudes and engagement in a large class setting. Journal of Service-learning in Higher Education, 6, 75-90.

Corbin, J.M., \& Strauss, A.L. (2008). Basics of Qualitative Research: Techniques and Procedures for Developing Grounded Theory ( $3^{\text {rd }}$ ed.). Sage.

Desimone, L. (2002). How can comprehensive school reform models be successfully implemented? Review of educational Research, 72(3), 433-479.

Duflo, E., Dupas, P., \& Kremer, M. (2012). School governance, teacher incentives, and pupil-teacher ratios: Experimental evidence from Kenyan schools. National Bureau of Economic Research, Working Paper Series, 1-44.

Ehrenberg, R.G., Brewer, D.J., Gamoran, A., \& Willms, J.D. (2001). Class size and student achievement. Psychological Science in the Public Interest, 2(1), 1-30. 
Chimbi, G. T. \& Jita, L. C. Resurgence of Large Class Sizes and Pedagogical Reform in 21st Century Secondary School History Classrooms

Fredriksson, P., Öckert, B., \& Oosterbeek, H. (2012). Long-term effects of class size. Institute for Evaluation of Labour Market and Education Policy: Working Paper 2012(5), 1-34.

Fullan, M., \& Miles, M.B. (1992). Getting reform right: What works and what doesn't. Phi Delta Kappan, 73(10), 745-752.

Garcia-Martinez, I. \& Tadeu, P. (2018). The impact of pedagogical leadership on pedagogical coordination in secondary schools. Research in Social Sciences and Technology, 3(3),

1-15. https://ressat.org/index.php/ressat/article/view/373/45

Glaser, B.G., \& Strauss, A.L. (1967). The Discovery of Grounded Theory: Strategies for Qualitative Research. Aldine de Gruyter.

Glass, G.V. \& Smith, M.L. (1979). Meta-analysis of research on class size and achievement. Educational Evaluation and Policy Analysis, 1(1), 1-16.

Hattie, J. (2009). Visible learning: A synthesis of over 800 meta-analyses related to achievement. Routledge.

Hewitt, J., \& Brett, C. (2007). The relationship between class size and online activity patterns in asynchronous computer conferencing environments. Computers and Education, 49(4), 1258-1271. Doi: 10.1016/j.compedu.2006.02.001

Hoxby, C.M. (2000). Effects of class size on student achievement: New evidence from population variation. The Quarterly Journal of Economics, 115(4), 1239-1285.

Jacob, O.A., Oluwuyi, B.O., \& Jacob, A.J. (2016). Relationship between class size and discipline of secondary school students in Yagba West of Kogi State, Nigeria. Sky Journal of Educational Research, 4(1), 8-13. http://www.skyjournals.org/SJER

Jepsen, C. (2015). Class size: Does it matter for student achievement? World of Labour. 1-10. wol.iza.org

Jita L.C., \& Mokhele, M.L. (2013). The role of lead teachers in instructional leadership: A case study of environmental learning in South Africa. Education as Change,17(sup1), S123S135. Doi: 10.1080/16823206.2014.865998

Klenke, K. (2016). Qualitative Research in the Study of Leadership ( $2^{\text {nd }}$ ed.). Emerald Publishing Ltd. ProQuest eBook Central. http://ebookcentral.proquest.com/lib/zouzwebooks/detail.action?doclD $=4500561$

Lowenthal, P.R., Nyland, R, Jung, F, Dunlap, J. C. \& Kepka, J. (2019). Does Class Size Matter? An exploration into faculty perceptions of teaching high-enrolment online courses. American Journal of Distance Education, 33(3), 152-168. Doi:10.1080/08923647.2019. 1610262

Marais, P. (2016). "We can't believe what we see": Overcrowded classrooms through the eyes of student teachers. South African Journal of Education, 36(2), 1-10.

Maringe, F., \& Sing, N. (2014). Teaching large classes in an increasingly internationalising higher education environment: Pedagogical, quality and equity issues. Higher Education, 67(6),761-782. Doi:10.07/s10734-013-9710-0

Ministry of Primary and Secondary Education, Zimbabwe [MOPSE]. (2015). Curriculum Framework for Primary and Secondary Education 2015-2022, MOPSE.

Molise, H. (2021). Pathways to mitigate challenges of learner academic performance in a Grade 10 economics class in South Africa. Research in Social Sciences and Technology, 6(1), 83-101. https://doi.org/10.46303/ressat.2021.5 
Chimbi, G. T. \& Jita, L. C. Resurgence of Large Class Sizes and Pedagogical Reform in 21st Century Secondary School History Classrooms

Mosteller, F. (1995). The Tennessee study of class size in the early school grades. Critical Issues for Children and Youth, 5(2), 113-127.

Ngcukana, L. (2018). Up to 100 pupils crammed into single classroom, City Press, 25 September. Opoku-Asare N.A., Agbenatoe W.G., \& DeGraft-Johnson K.G. (2014). Instructional strategies, institutional support and student achievement in general knowledge in art: Implications for visual arts education in Ghana. Journal of Education and Practice, 5(21), 121-134.

Orellana, A. (2006). Class size and interaction in online courses. Quarterly Review of Distance Education, 7(3), 229-248.

Parks-Stamm, E.J., Zafonte, M. \& Palenque, S.M. (2016). The effects of instructor participation and class size on student participation in an online class discussion forum. British Journal of Educational Technology, 48(6), 1-14. Doi:10.1111/bjet.12512

Plummer, K. (2000). A world in the making: Symbolic Interactionism in the Twentieth Century. The Blackwell Companion to Sociology $\left(2^{\text {nd }}\right.$ ed). Blackwell.

Ritzer, G., \& Smart, B. (2001). Introduction: Theorists, Theories and Theorizing. In Ritzer, G. \& Smart, B. (Eds.). Handbook of Social Theory (pp. 1-12). Sage.

Sandstrom, K. L., Martin, D. D., \& Fine, G.A. (2001). Symbolic Interactionism at the End of the Century. In Ritzer, G. \& Smart, B. (Eds.). Handbook of Social Theory (pp. 217-231). Sage.

Smith, M.L., \& Glass, G.V. (1980). Meta-analysis of research on class size and its relationship to attitudes and instruction. American Educational Research Journal, 17(4), 419-433.

The Editor, (2017). Teacher-pupil ratio cause for concern. Daily News, 7 March.

UNESCO, (2017). Summary Report of the 2015 UIS Innovation Data Collection. Information Paper No. 37 March 2017, UNESCO Institute of Statistics.

Venktess, K. (2011). 150 pupils in one classroom. Mercury, 10 March.

Wadesango, N., Hove, J., \& Kurebwa, M. (2016). Effects of a large class size on effective curriculum implementation. International Journal of Educational Sciences, 12(2), 173183.

Wright, M.C., Bergom, I., \& Bartholomew, T. (2017). Decreased class size, increased active learning? Intended and enacted teaching strategies in smaller classes. Active Learning in Higher Education, 20(1), 51-62.

_DOI: 10.1177/1469787417735607 journals.sagepub.com/home/alh

Zikhali J., Chauraya E., Madzanire D., \& Maphosa C. (2015). An exploration of factors affecting students' studies in one selected university in Zimbabwe. International Journal of Educational Sciences, 9(2), 243-254. 